\title{
Short communication: Microbiological quality of raw cow milk and its association with herd management practices in Northern China
}

\author{
X. Y. Lan, ${ }^{*}+\ddagger^{1}$ S. G. Zhao, ${ }^{* 1}$ N. Zheng, ${ }^{*}$ S. L. Li, ${ }^{*}$ Y. D. Zhang, ${ }^{*}$ H. M. Liu, ${ }^{*}$ J. McKillip,§ and J. Q. Wang ${ }^{* 2}$ \\ *Laboratory of Quality and Safety Risk Assessment for Dairy Products of Ministry of Agriculture (Beijing), Institute of Animal Sciences, \\ Chinese Academy of Agricultural Sciences, Beijing 100193, P. R. China \\ †College of Animal Science and Technology, Hunan Agricultural University, Changsha 410128, Hunan Province, P. R. China \\ $\ddagger$ College of Animal Science and Technology, Gansu Agricultural University, Lanzhou 730070, Gansu Province, P. R. China \\ §Department of Biology, Ball State University, Muncie, IN 47306
}

\section{ABSTRACT}

Contamination of raw milk with bacterial pathogens is potentially hazardous to human health. The aim of this study was to evaluate the total bacteria count (TBC) and presence of pathogens in raw milk in Northern China along with the associated herd management practices. A total of 160 raw milk samples were collected from 80 dairy herds in Northern China. All raw milk samples were analyzed for TBC and pathogens by culturing. The results showed that the number of raw milk samples with $\mathrm{TBC}<2 \times 10^{6} \mathrm{cfu} / \mathrm{mL}$ and $<1 \times 10^{5} \mathrm{cfu} / \mathrm{mL}$ was $146(91.25 \%)$ and $70(43.75 \%)$, respectively. A total of $84(52.50 \%)$ raw milk samples were Staphylococcus aureus positive, $72(45.00 \%)$ were Escherichia coli positive, 2 (1.25\%) were Salmonella positive, $2(1.25 \%)$ were Listeria monocytogenes positive, and $3(1.88 \%)$ were Campylobacter positive. The prevalence of $S$. aureus was influenced by season, herd size, milking frequency, disinfection frequency, and use of a Dairy Herd Improvement program. The TBC was influenced by season and milk frequency. The correlation between TBC and prevalence of $S$. aureus or $E$. coli is significant. The effect size statistical analysis showed that season and herd (but not Dairy Herd Improvement, herd size, milking frequency, disinfection frequency, and area) were the most important factors affecting TBC in raw milk. In conclusion, the presence of bacteria in raw milk was associated with season and herd management practices, and further comprehensive study will be powerful for effectively characterizing various factors affecting milk microbial quality in bulk tanks in China.

Key words: raw milk, total bacterial count, pathogen, management practice, Northern China

\footnotetext{
Received June 17, 2016.

Accepted March 2, 2017.

${ }^{1}$ These authors contributed equally to this work.

${ }^{2}$ Corresponding author: jiaqiwang@vip.163.com
}

\section{Short Communication}

Milk is a nutritious food for humans as well as an ideal growth medium for bacterial pathogens (Ruusunen et al., 2013). Commonly, serious outbreaks of foodborne disease have been traced back to consumption of milk or dairy products contaminated by pathogens such as Escherichia coli, Salmonella, Listeria monocytogenes, or Campylobacter spp. (Quigley et al., 2013; Cerva et al., 2014). A total of 13 reported outbreaks were associated with Shiga toxin-producing E. coli in unpasteurized milk in the United States from 2007 to 2012 (Mungai et al., 2015). Salmonella outbreaks were associated with raw milk and dairy products. Dairy products have been implicated in approximately half of all listeriosis outbreaks in Europe (Parisi et al., 2013). The number of reported foodborne disease outbreaks in the United States caused by unpasteurized milk increased from 30 cases between 2007 and 2009 to 51 cases between 2010 and 2012, and the number of Campylobacter spp. outbreaks approximately doubled (Mungai et al., 2015). Although these hazards are well known worldwide, little information is available about pathogen contamination rates of raw milk in China.

Total bacterial count (TBC), an estimate of quality of raw milk, has become one of the accepted criteria for grading milk (Mhone et al., 2011). High-quality raw milk has a low TBC (Oliver et al., 2009). In the United States, the Pasteurized Milk Ordinance requires grade A raw milk to have a TBC of $<1 \times 10^{5} \mathrm{cfu} / \mathrm{mL}$ (FDA, 2013) - the same level as mandated in Europe (Piepers et al., 2014). In China, the national standard requires raw milk to have a TBC of $<2 \times 10^{6} \mathrm{cfu} / \mathrm{mL}$ (National Standards of the Republic of China, 2010a). Most dairy herds in China fall into 1 of 2 categories: those with modern feeding systems (most of these are in Beijing) and those with traditional feeding systems (mostly in Inner Mongolia). Northern China, including Beijing and Inner Mongolia, is the nation's major milk-producing area. However, information about the 
microbiological quality of raw milk and associated factors in Northern China is limited. The aim of this study was to investigate levels of TBC and the prevalence of Staphylococcus aureus, E. coli, Salmonella, L. monocytogenes, and Campylobacter in raw milk samples collected from dairy herds in Northern China and evaluate the factors influencing raw milk microbial quality.

A total of 160 raw milk samples were collected from 80 dairy herds from 2 regions of Northern China: Inner Mongolia and Beijing. The raw milk samples were collected in summer (August and September 2014; average daily temperature $>20^{\circ} \mathrm{C}$ ) and winter (October and November 2014; average daily temperature $<10^{\circ} \mathrm{C}$ ). All raw milk samples were sampled from a bulk tank $\left(3-5^{\circ} \mathrm{C}\right)$, transferred to sterile bottles, stored at approximately $4^{\circ} \mathrm{C}$, and transported to the local laboratory for microbiological analyses within $24 \mathrm{~h}$ of sampling.

Information on management practices of dairy herds was obtained by interview with farm managers during sampling. Information included total number of cattle, frequency of milking per day, frequency of disinfection of milking machine unit liner per day, DHI program, and common hygienic measures.

The raw milk samples were analyzed for TBC, $S$. aureus, and E. coli by plate counts. Salmonella, L. monocytogenes, and Campylobacter spp. in raw milk were analyzed by the International Organization for Standardization standard methods (National Standards of the Republic of China, 2010b; ISO, 1999, 2001, 2002, 2004, 2006; Supplemental Table S1; https://doi. org/10.3168/jds.2016-11631).

All statistical analysis was performed using SAS/ Stat software (version 9.2; SAS Institute Inc., 2008). The TBC $\left(\log _{10} \mathrm{cfu} / \mathrm{mL}\right)$ were analyzed using the following model:

$$
\begin{aligned}
Y_{i j k l m n o} & =\mu+S_{i}+A_{j}+H S_{k}+D_{l}+M F_{m} \\
& +D i s F_{n}+H_{j k l m n o}+E_{i j k l m n o},
\end{aligned}
$$

where $Y_{i j k l m n o}$ is the dependent variable, $\mu$ is the mean, $S_{i}$ is the effect of the $i$ th season (summer or winter); $A_{j}$ is the effect of the $j$ th area; $H S_{k}$ is the effect of the $k$ th herd size; $D_{l}$ is the effect of the lth level of implementation of DHI; $M F_{m}$ is the effect of the $m$ th frequency of milking per day; $D i s F_{n}$ is the effect of the $n$th level of frequency of disinfection of the milking machine unit liner per day; $H_{j k l m n o}$ is the effect of the oth herd within the $j$ th area, $k$ th herd size, lth DHI level, $m$ th milking frequency level, and $n$th disinfection frequency level; and $E_{i j k l m n o}$ is the residual error. All factors except herd were considered to be fixed effects; herd was considered to be a random effect. All herds were sampled in both seasons, but for the other factors, each herd was characterized by 1 level of each factor. It was not possible to include interaction terms in the model due to the relatively small size of the data set. The relative importance of each factor was determined using the effect size option in the GLM procedure. These effect sizes were determined as the proportion of the sums of squares (Type III) for each factor in the model relative to the total sums of squares [referred to as semipartial eta squared $\left(\eta^{2}\right)$ in SAS according to Hoefkens et al. (2011)]. The model described here was also analyzed using the MIXED procedure to test hypotheses about the significance of the fixed effects. The Kenward-Roger option was used to determine the appropriate degrees of freedom for each test.

A chi-squared test $\left(\chi^{2}\right)$ using the FREQ procedure of SAS was used to assess associations between the prevalence of $S$. aureus and $E$. coli pathogens and the following factors: season, region, herd size, DHI implementation, frequency of milking per day, and frequency of disinfection of milking machine unit liner per day. A regression analysis (using the REG procedure of SAS) was carried out to determine the relationship between $S$. aureus or E. coli and TBC (all values as $\log _{10} \mathrm{cfu} /$ $\mathrm{mL}$ ), and only samples with positive counts of $S$. aureus and $E$. coli were used for these analyses. The factors

\begin{tabular}{|c|c|c|c|c|}
\hline Item & $\begin{array}{c}\text { Positive samples } \\
{[\text { no. }(\%)]}\end{array}$ & $\begin{array}{l}\text { Count range in } \\
\text { positive samples } \\
\left(\log _{10} \mathrm{cfu} / \mathrm{mL}\right)\end{array}$ & $\begin{array}{l}\text { Average count in } \\
\text { positive samples } \\
\left(\log _{10} \mathrm{cfu} / \mathrm{mL}\right)\end{array}$ & $\begin{array}{c}\text { Average count } \\
\text { in total samples } \\
\left(\log _{10} \mathrm{cfu} / \mathrm{mL}\right)\end{array}$ \\
\hline$\overline{\mathrm{TBC}}$ & $\mathrm{ND}^{1}$ & $3.15-6.61$ & ND & 5.10 \\
\hline Staphylococcus aureus & $84(52.5)$ & $1-4.73$ & 2.79 & 1.47 \\
\hline Escherichia coli & $72(45)$ & $1-4.83$ & 2.91 & 1.31 \\
\hline Salmonella & $2(1.25)$ & ND & ND & ND \\
\hline
\end{tabular}

Table 1. Total bacteria count (TBC) and pathogen prevalence in raw milk samples $(\mathrm{n}=160)$ in Northern China

${ }^{1} \mathrm{ND}=$ not determined. 
listed previously (season, area, herd size, DHI implementation, frequency of milking per day, and frequency of disinfection of milking machine unit liner per day) were included in the model, one at a time, to determine effects on slopes and intercepts. The zero value was not analyzed.

Among all 160 raw milk samples, the TBC varied from 3.15 to $6.61 \log _{10} \mathrm{cfu} / \mathrm{mL}$, with the average of 5.10 $\log _{10} \mathrm{cfu} / \mathrm{mL}$ (Table 1). The average TBC in our study is lower than that in Morocco $\left(5.87 \log _{10} \mathrm{cfu} / \mathrm{mL}\right.$; Sraïri et al., 2009) and Zimbabwe $\left(6.4 \log _{10} \mathrm{cfu} / \mathrm{mL}\right.$; Mhone et al., 2011) but higher than that in Belgium (3.96 $\log _{10}$ $\mathrm{cfu} / \mathrm{mL}$; Piepers et al., 2014), the United States (4.06 $\log _{10} \mathrm{cfu} / \mathrm{mL}$; van Schaik et al., 2002), or Finland (4.11 $\log _{10} \mathrm{cfu} / \mathrm{mL}$; Ruusunen et al., 2013). Approximately $92 \%$ of raw milk samples met the TBC of the China national standard $\left(<200 \times 10^{4} \mathrm{cfu} / \mathrm{mL}\right)$, and approximately $44 \%$ of the raw milk samples met the TBC standards $\left(<10 \times 10^{4} \mathrm{cfu} / \mathrm{mL}\right)$ of the United States and Europe (Piepers et al., 2014; Table S2; https://doi. org/10.3168/jds.2016-11631).

Staphylococcus aureus, E. coli, Salmonella, L. monocytogenes, and Campylobacter were positive in 84 (52.50\%), 72 (45.00\%), $2(1.25 \%), 3(1.88 \%)$, and 2 $(1.25 \%)$ raw milk samples, respectively (Table 1$)$. The prevalence of $S$. aureus in our study is lower than that in Italy (83\%; Bartolomeoli et al., 2009) but higher than that in Finland (34.4\%; Ruusunen et al., 2013). The prevalence of $E$. coli in raw milk in our study was lower than that in Malaysia $(64.5 \%)$ but higher than that in the United States (3.8\%; Jayarao and Henning, 2001). The prevalence of Salmonella in our study is lower than that in Malaysia (1.4\%) and the United States (2.6\%; Van Kessel et al., 2004) but higher than that in New Zealand (0\%; Hill et al., 2012) and Italy (0.3\%; Bianchi et al., 2013). The prevalence of L. monocytogenes in our study is lower than that in Finland (5.5\%; Ruusunen et al., 2013) but higher than that in New Zealand $(0.68 \%$; Hill et al., 2012). The prevalence of Campylobacter in our study is lower than that in Poland $(4.6 \%$; Wysok et al., 2011) and the United States (36.6\%; Sanad et al., 2014 ) but higher than that in New Zealand (0.34\%; Hill et al., 2012).

The TBC and prevalence of $S$. aureus and E. coli in raw milk samples from winter were significantly lower than in samples from summer (Table 2), which was not surprising considering the longer generation time of bacteria in a bulk tank in winter. Frequency of milking was a significant effector of TBC such that herds that milked 3 times/d had a lower TBC level than herds that milked 2 times/d. The prevalence of $S$. aureus was lower $(P<0.01)$ in large dairy herds than in small herds, lower $(P<0.05)$ with an implemented DHI system than without a DHI system, and lower $(P<0.01)$

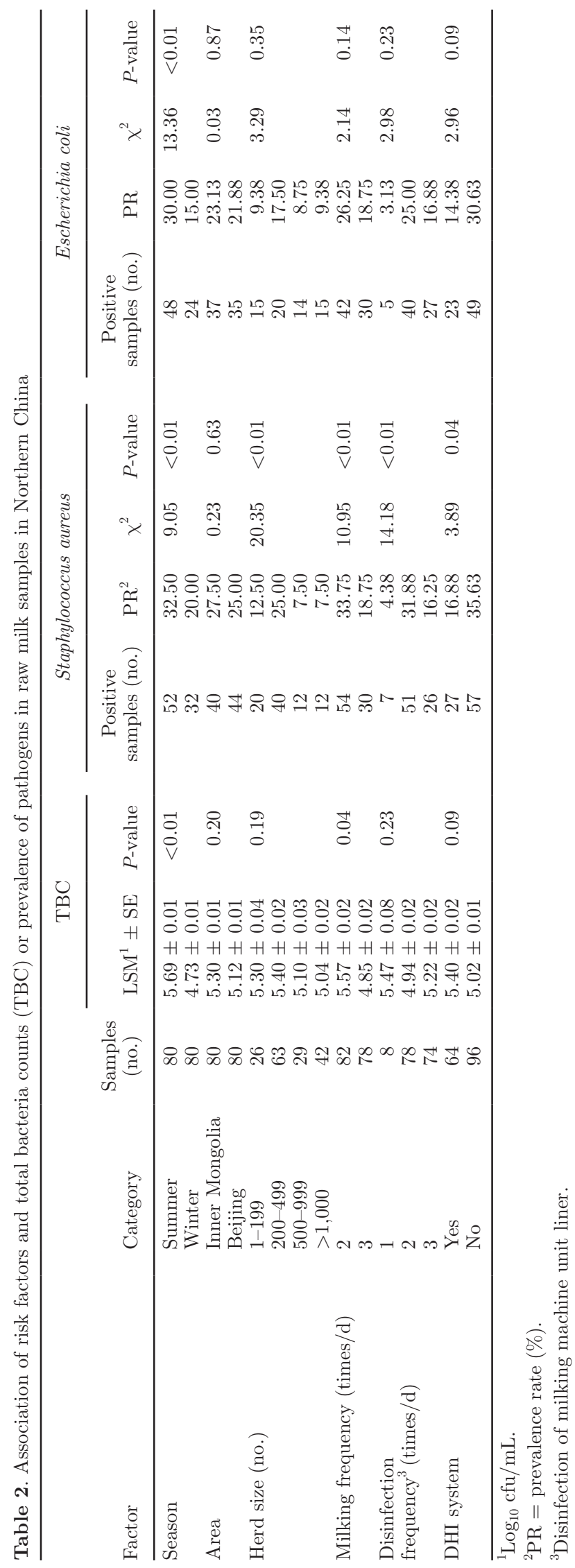



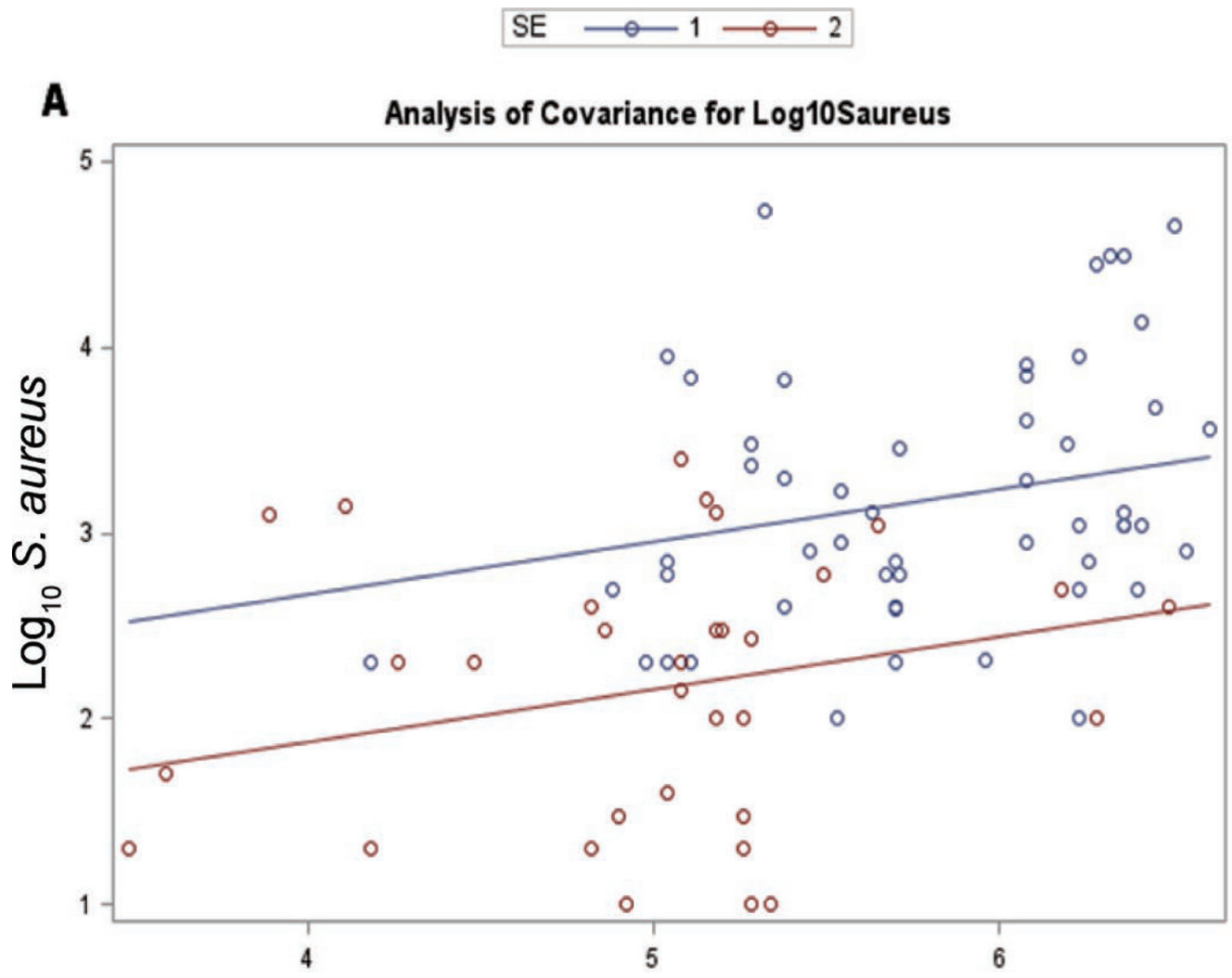

B

Analysis of Covariance for Log10Ecoli

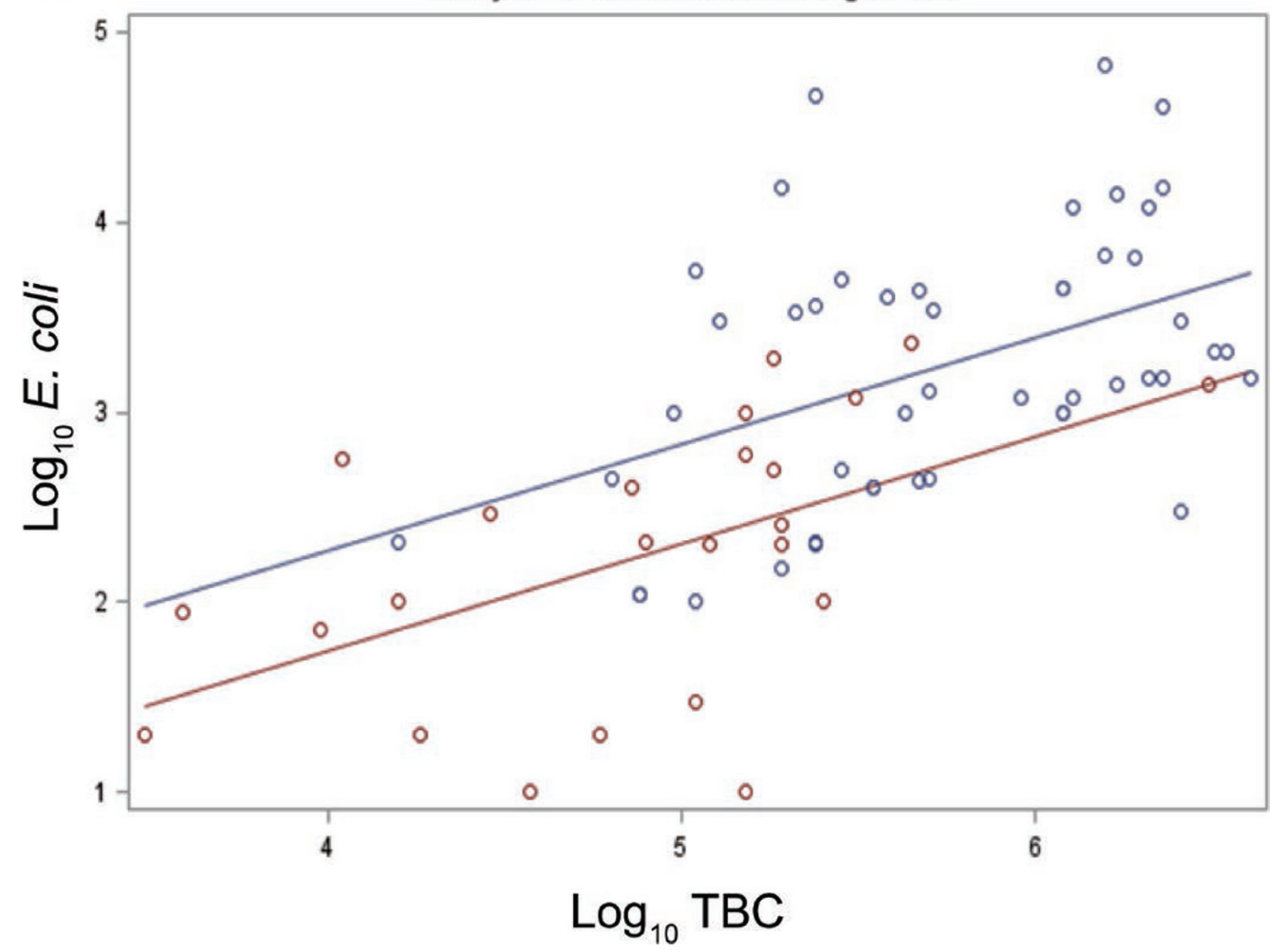

Figure 1. Regression analyses of relationships for (A) Staphylococcus aureus counts and total bacteria counts and (B) Escherichia coli counts and total bacteria counts (TBC) of raw milk in Northern China. SE = season; $1=$ summer; $2=$ winter. Color version available online. 


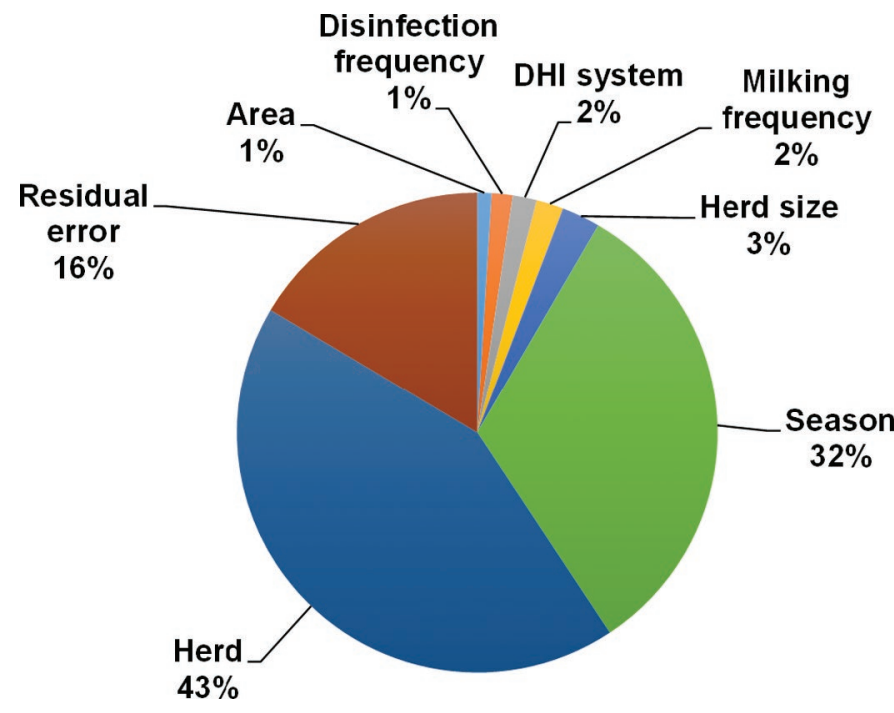

Figure 2. The relative importance of factors affecting total bacteria counts in raw milk expressed as semipartial eta values $\left(\eta^{2}\right)$, which represent percentages of the Type III sums of squares attributed to the various effects in the model. Color version available online.

with increasing milking frequency and frequency of disinfection of milking machine unit liner. The prevalence of $S$. aureus in raw milk commonly indicates mastitis in dairy herds (Cicconi-Hogan et al., 2014). The lower prevalence of $S$. aureus from large dairy herds may be attributable to more stringent hygienic and managerial practices implemented in the large herds (CicconiHogan et al., 2013; Toth et al., 2013). Approximately $80 \%$ of our selected large dairy herds implemented DHI, which was associated with a lower prevalence of $S$. aureus. The prevalence and high level of E. coli in food of animal origin implies environmental and fecal contamination (Mhone et al., 2011). In this study, only season was found to be a significant effect factor for the presence of $E$. coli. However, others have reported that some herd management practices were associated with E. coli contamination, such as milking machine, milking parlor type, and milking hygiene (Pantoja et al., 2009; Mhone et al., 2011; Piepers et al., 2014). A significant correlation was found between TBC and prevalence of S. aureus $\left(P<0.01, \mathrm{R}^{2}=0.23\right)$ and $E$. coli $(P<0.01$, $\mathrm{R}^{2}=0.41 ;$ Figure 1$)$. This suggests that more attention should be paid to $S$. aureus and E. coli when TBC counts of milk are unusually high.

Considering the relative importance of factors affecting TBC expressed as semipartial eta values $\left(\eta^{2}\right)$, we see that season $\left(\eta^{2}=30.0 \%\right)$ and herd $\left(\eta^{2}=39.8 \%\right)$ were most important, whereas area, herd size, and herd management factors such as use of DHI, milking frequency, and disinfection frequency were relatively unimportant (Figure 2). The proportion of variance at- tributed to error in this analysis was found to be $\eta^{2}=$ $15.2 \%$. Because the relative importance of herd-to-herd differences is so large $\left(\eta^{2}=39.8 \%\right)$, important elements of herd management that are not presently known must be affecting TBC. Previous studies revealed that herd size and cleaning frequency were significantly associated with TBC in raw milk (Piepers et al., 2014). This suggests that TBC in raw milk is primarily driven by herd factors other than the ones included in this study, potentially including the length of time in the bulk tank, storage temperature, methods of premilking and postmilking teat sanitation, or incidence of mastitis.

In conclusion, we found that the majority of raw milk samples met the TBC of the China national standard. The prevalence of $S$. aureus and E. coli in raw milk was much higher than that of other bacterial species. Season, herd size, DHI implementation, milking frequency, and disinfection frequency were associated with microbiological quality in raw milk. However, those herd management factors could not explain all variations of TBC in raw milk. Therefore, further research should analyze how other herd factors affect TBC in raw milk.

\section{ACKNOWLEDGMENTS}

This work was supported by Fundamental Research Funds for the Central Non-Profit Research Institution (2015ywf-zd-3), Special Fund for Agro-Scientific Research in the Public Interest (201403071), Project of Risk Assessment on Raw Milk (GJFP2015008), and the Agricultural Science and Technology Innovation Program (ASTIP-IAS12). We are grateful to Gary Crow (University of Manitoba, Winnipeg, Canada) for the statistical analysis and Nicole H. Martin (Cornell University, Ithaca, NY) for the suggestions on the manuscript.

\section{REFERENCES}

Bartolomeoli, I., M. Maifreni, F. Frigo, G. Urli, and M. Marino. 2009 Occurrence and characterization of Staphylococcus aureus isolated from raw milk for cheesemaking. Int. J. Dairy Technol. 62:366-371.

Bianchi, D. M., A. Barbaro, S. Gallina, N. Vitale, L. Chiavacci, M. Caramelli, and L. Decastelli. 2013. Monitoring of foodborne pathogenic bacteria in vending machine raw milk in Piedmont, Italy. Food Contr. 32:435-439.

Cerva, C., C. Bremm, E. M. Reis, A. V. Bezerra, M. R. Loiko, C. E. Cruz, A. Cenci, and F. Q. Mayer. 2014. Food safety in raw milk production: Risk factors associated to bacterial DNA contamination. Trop. Anim. Health Prod. 46:877-882.

Cicconi-Hogan, K. M., N. Belomestnykh, M. Gamroth, P. L. Ruegg, L. Tikofsky, and Y. H. Schukken. 2014. Short communication: Prevalence of methicillin resistance in coagulase-negative staphylococci and Staphylococcus aureus isolated from bulk milk on organic and conventional dairy farms in the United States. J. Dairy Sci. 97:2959-2964

Cicconi-Hogan, K. M., M. Gamroth, R. Richert, P. L. Ruegg, K. E. Stiglbauer, and Y. H. Schukken. 2013. Associations of risk factors 
with somatic cell count in bulk tank milk on organic and conventional dairy farms in the United States. J. Dairy Sci. 96:3689-3702.

FDA (U. S. Food and Drug Administration). 2013. Grade "A" Pasteurized Milk Ordinance. U.S. Department of Health and Human Services, Washington, DC.

National Standards of the Republic of China. 2010a. National food safety standard GB19301: Raw milk. Minister of Health of the People's Republic of China, Beijing.

National Standards of the Republic of China. 2010b. National food safety standard GB4789.2: Food microbiological examination: Aerobic plate count. Minister of Health of the People's Republic of China, Beijing.

Hill, B., B. Smythe, D. Lindsay, and J. Shepherd. 2012. Microbiology of raw milk in New Zealand. Int. J. Food Microbiol. 157:305-308.

Hoefkens, C., W. Verbeke, and J. Van Camp. 2011. European consumers' perceived importance of qualifying and disqualifying nutrients in food choices. Food Qual. Prefer. 22:550-558.

ISO (International Organization for Standardization). 1999. Horizontal method for the enumeration of coagulase-positive staphylococci (Staphylococcus aureus and other species). Part 1. Technique using Baird-Parker agar medium. Standard number 6888-1. ISO, Geneva, Switzerland.

ISO (International Organization for Standardization). 2001. Horizontal method for the enumeration of beta-glucuronidase-positive Escherichia coli. Part 2: Colony-count technique at $44^{\circ} \mathrm{C}$ using 5-bromo-4-chloro-3-indolyl beta-D-glucuronide. Standard number 16649-2. ISO, Geneva, Switzerland.

ISO (International Organization for Standardization). 2002. Horizontal method for the detection of Salmonella spp. Standard number 6579. ISO, Geneva, Switzerland.

ISO (International Organization for Standardization). 2004. Horizontal method for the detection and enumeration of Listeria monocytogenes. Standard number 11290. ISO, Geneva, Switzerland.

ISO (International Organization for Standardization). 2006. Horizontal method for detection and enumeration of Campylobacter spp. Part 1: Detection method. Standard number 10272-1. ISO, Geneva, Switzerland.

Jayarao, B. M., and D. R. Henning. 2001. Prevalence of foodborne pathogens in bulk tank milk. J. Dairy Sci. 84:2157-2162.

Mhone, T. A., G. Matope, and P. T. Saidi. 2011. Aerobic bacterial, coliform, Escherichia coli and Staphylococcus aureus counts of raw and processed milk from selected smallholder dairy farms of Zimbabwe. Int. J. Food Microbiol. 151:223-228.

Mungai, E. A., C. B. Behravesh, and L. H. Gould. 2015. Increased outbreaks associated with nonpasteurized milk, United States, 2007-2012. Emerg. Infect. Dis. 21:119-122.
Oliver, S. P., K. J. Boor, S. C. Murphy, and S. E. Murinda. 2009. Food safety hazards associated with consumption of raw milk. Foodborne Pathog. Dis. 6:793-806.

Pantoja, J. C., D. J. Reinemann, and P. L. Ruegg. 2009. Associations among milk quality indicators in raw bulk milk. J. Dairy Sci. 92:4978-4987.

Parisi, A., L. Latorre, R. Fraccalvieri, A. Miccolupo, G. Normanno, M. Caruso, and G. Santagada. 2013. Occurrence of Listeria spp. in dairy plants in Southern Italy and molecular subtyping of isolates using AFLP. Food Contr. 29:91-97.

Piepers, S., P. Zrimsek, P. Passchyn, and S. De Vliegher. 2014. Manageable risk factors associated with bacterial and coliform counts in unpasteurized bulk milk in Flemish dairy herds. J. Dairy Sci. 97:3409-3419

Quigley, L., O. O'Sullivan, C. Stanton, T. P. Beresford, R. P. Ross, G. F. Fitzgerald, and P. D. Cotter. 2013. The complex microbiota of raw milk. FEMS Microbiol. Rev. 37:664-698.

Ruusunen, M., M. Salonen, H. Pulkkinen, M. Huuskonen, S. Hellstrom, J. Revez, M. L. Hanninen, M. Fredriksson-Ahomaa, and M. Lindstrom. 2013. Pathogenic bacteria in Finnish bulk tank milk. Foodborne Pathog. Dis. 10:99-106.

Sanad, Y. M., K. Jung, I. Kashoma, X. L. Zhang, I. I. Kassem, Y. M. Saif, and G. Rajashekara. 2014. Insights into potential pathogenesis mechanisms associated with Campylobacter jejuni-induced abortion in ewes. BMC Vet. Res. 10:274.

SAS Institute. 2008. SAS/STAT 9.2 User's Guide. SAS Institute, Cary, $\mathrm{NC}$

Sraïri, M. T., H. Benhouda, M. Kuper, and P. Y. Le Gal. 2009. Effect of cattle management practices on raw milk quality on farms operating in a two-stage dairy chain. Trop. Anim. Health Prod. 41:259-272.

Toth, J. D., H. W. Aceto, S. C. Rankin, and Z. Dou. 2013. Short communication: Survey of animal-borne pathogens in the farm environment of 13 dairy operations. J. Dairy Sci. 96:5756-5761.

Van Kessel, J. S., J. S. Karns, L. Gorski, B. J. McCluskey, and M. L. Perdue. 2004. Prevalence of Salmonellae, Listeria monocytogenes, and fecal coliforms in bulk tank milk on US dairies. J. Dairy Sci. 87:2822-2830.

van Schaik, G., M. Lotem, and Y. H. Schukken. 2002. Trends in somatic cell counts, bacterial counts, and antibiotic residue violations in New York State during 1999-2000. J. Dairy Sci. 85:782-789.

Wysok, B., A. Wiszniewska-Laszczych, J. Uradzinski, and J. Szteyn. 2011. Prevalence and antimicrobial resistance of Campylobacter in raw milk in the selected areas of Poland. Pol. J. Vet. Sci. 14:473477. 